\title{
THE CONCEPT OF IMPLEMENTING THE ACTIVITY-BASED COSTING IN MULTI-ASSORTMENT MANUFACTURING ENTERPRISE - THEORETICAL ASPECTS (PART 1)
}

\author{
Daria MOSKWA-BĘCZKOWSKA \\ Kielce University of Technology, The Chair of Economic and Finance, Poland; dariam@tu.kielce.pl, \\ ORCID: 0000-0003-2165-6829
}

Purpose: The main objective of the article is to develop and present a concept for the implementation of activity-based costing in a company dealing with multi-assortment production of bookbinding machinery. However, due to the publishing requirements, the article was divided into two parts - the first one describes the theoretical approach to the problem and the second one presents the case study. Therefore, the aim of this part of the considerations is to present the shortcomings of traditional methods of unit cost calculation in the light of the literature on the subject and to present the main assumptions and calculation procedures of the concept of activity-based costing.

Design/methodology/approach: The main research methods used in this part of the considerations are: analysis of the literature on the subject and inference.

Findings: The result of the research is the conclusion that the traditional methods of unit cost calculation, i.e. full costing and variable costing, are insufficient for effective cost management in the company.

Originality/value: This part of the analysis presents in a synthetic way the identified main disadvantages of traditional unit costing methods. An alternative solution to the discussed problem was also presented here, i.e. the change of the applied costing system into an activitybased costing system - analyzing its assumptions and calculation procedures. This content is directed both to persons dealing with these matters from the theoretical perspective, as well as company owners and heads of controlling or production departments.

Keywords: activity-based costing, implementation of, multi-assortment production.

Category of the paper: research paper, case study.

\section{Introduction}

Effective management of business activity, regardless of its profile or organizational and legal form, is inseparably connected with making rational economic decisions. These, in turn, are determined - above all - by the amount and structure of costs incurred by the company, 
being the starting point for both operational and strategic decisions. The tool that collects and organizes information about the costs incurred in the company is a cost account, the main task of which is to provide reliable and credible cost data. This data is particularly relevant for manufacturing enterprises with a high degree of complexity of manufacturing processes. For such entities, determining the level and structure of own costs of products is one of the most important issues in assessing the efficiency of manufacturing processes. Unfortunately, traditional costing systems, such as full costing or variable costing often do not meet the demanding information needs of the enterprise management. Therefore, they more and more often decide to change their existing costing system to another one adapted to their internal needs. Companies are looking for other, modern costing concepts - such as, for example, activity-based costing - which are simply becoming a necessity in the face of their growing information requirements.

In the light of the above considerations, the main objective of the article is to develop and present a concept for the implementation of activity-based costing in a company dealing with multi-assortment production. Due to the fact that the article was divided into two parts theoretical aspects of the analyzed problem and a case study of the examined costing method for a specific company - specific objectives were also formulated. The aim of this part of the considerations is to present the shortcomings of traditional methods of unit cost calculation in the light of the literature on the subject and to present the main assumptions and calculation procedures of the concept of activity-based costing.

\section{Traditional costing systems}

Analysis and evaluation of the size and structure of costs, including in particular unit costs, is one of the most important elements of efficient operation of a company. The tool of the accounting system used to collect information on costs is the so-called costing, which enables their presentation in different classification profiles (Nowak, 1996). In the literature, it is most often defined as a set of cost information relatively separate (subjectively and procedurally) in a business entity's information system, developed according to a specific model, adjusted to the information needs of its users (cf. e.g: Raiborn, Kinney, 2010). The set of information obtained from the costing system is used to:

- determine unit costs of manufacturing of products,

- periodically determine the result of business activity,

- set prices of manufactured products,

- assess profitability and management efficiency,

- make various economic decisions. 
Achieving the above objectives is possible thanks to a number of activities carried out in the costing system. These activities and their detailed characteristics are presented in Table 1.

Table 1.

The objective scope of the costing

\begin{tabular}{|l|l|}
\hline \multicolumn{1}{|c|}{$\begin{array}{c}\text { The object } \\
\text { of the costing }\end{array}$} & \multicolumn{1}{c|}{ Description } \\
\hline $\begin{array}{l}\text { Cost } \\
\text { measurement } \\
\text { and valuation }\end{array}$ & $\begin{array}{l}\text { the quality of the cost information depends on the accuracy of the measurement; } \\
\text { the measurement may be direct or estimated in terms of quantity or value; } \\
\text { the valuation is used in the case of quantitative measurement of the production factors used, } \\
\text { the results of which are multiplied by the relevant prices or rates; }\end{array}$ \\
\hline Documentation & $\begin{array}{l}\text { the results of cost measurement and their valuation must be included in the relevant } \\
\text { accounting documentation; cost documentation is usually secondary documentation, as data } \\
\text { from source documents are used to prepare it; }\end{array}$ \\
\hline $\begin{array}{l}\text { Cost recording } \\
\text { and its } \\
\text { allocation }\end{array}$ & $\begin{array}{l}\text { cost recording consists of recording costs on accounts and grouping them in appropriate } \\
\text { profiles (layouts); business entities have the right to choose a variant of cost recording } \\
\text { adapted to their specificity and needs; }\end{array}$ \\
\hline $\begin{array}{l}\text { Calculation of } \\
\text { costs }\end{array}$ & $\begin{array}{l}\text { consists in determining the unit cost by means of calculation methods adapted to the } \\
\text { characteristics of the production process; }\end{array}$ \\
\hline Cost reporting & $\begin{array}{l}\text { consists in preparation of obligatory statements resulting from the provisions of the balance } \\
\text { sheet law, e.g. the profit and loss account; }\end{array}$ \\
\hline Costs analysis & $\begin{array}{l}\text { consists in examining costs in relation to their structure in different dynamic profiles (with } \\
\text { a fixed and variable base), other business units or average volumes, planning or } \\
\text { benchmarking assumptions. }\end{array}$ \\
\hline
\end{tabular}

Source: Own elaboration based on T. Kiziukiewicz, Zarzadcze aspekty rachunkowości, PWE, Warsaw 2003, p. 145.

From the point of view of achieving the objective of this article, the key elements of a properly constructed costing system are the recording, accounting and calculating of the costs. When establishing its personalized costing system, the company must therefore pay attention to the following (Dobija, 1997):

- the selection of an appropriate variant of cost recording adapted to its needs, depending on which it can apply a simplified or extended variant of cost recording,

- the appropriate division of costs according to the criteria used to classify them, e.g. taking into account the cost behavior in relation to the size of the business is extremely important in terms of decision making and planning,

- the method of product valuation - whether it will be carried out on the basis of direct costs, variable costs or full production cost,

- the cost calculation method that should be adapted to the nature of the business,

- the way the data is processed in the costing, as well as its relationship with the management information system.

The above requirements become a necessity in creating a proper costing system and their task is to facilitate the measurement and transformation of cost information from the point of view of its users' needs.

The need to obtain more and more accurate information on costs has forced the emergence of many of its varieties, referred to in the literature as systems or models, classified on the basis of various criteria (however, not analyzed in detail here). One of the most popular costing 
systems are the so-called traditional costing systems, which include full costing and variable costing - both relatively extensively described in the literature on the subject (cf. e.g: Dobija, 1995; Gabrusewicz, Kamela-Sowińska, Poetschke, 2002; Nowak, Piechota, Wierzbiński, 2004; Nowak, Wierzbiński, 2010; Świderska, 2003). From the point of view of further consideration, the full costing is of greater importance, and therefore the most important issues relating to this costing will be addressed in synthetic considerations.

Full costing is the system that started to be applied the earliest in business entities in particular, it concerned companies where a limited and small number of products were manufactured and the costs of materials and direct payroll were a significant part of their manufacturing costs. Its basic thesis is the assumption that the costs of the products are all costs incurred in the unit in relation to their manufacture (Gabrusewicz, Kamela-Sowińska, Poetschke, 2002). The adjective 'full' used in the name of this costing therefore refers to the need to allocate all production costs to the products manufactured. Its characteristic feature is the division of production costs into direct and indirect costs. As mentioned above, direct costs are directly related to products on the basis of the collected source documentation, while indirect costs, after preliminary recognition according to their origin or function, are contractually allocated to products (Sołtys, 2014). This allocation is possible thanks to the use of so-called allocation keys ensuring a proportional distribution of indirect cost to manufactured products.

The key issue of the full costing is the method of costing that takes into account the principle of product valuation in the so-called full cost of manufacture, which means that all manufacturing costs are allocated to the finished products and to the production in progress. Moreover, the costing also includes the so-called non-manufacturing costs arising independently of the manufacturing activities undertaken by the facility, including management, marketing and sales costs. These costs are not an element of the cost of manufacturing of a product, which means that they are not counted towards to the value of the inventory of finished goods, but are directly recognized in the financial result.

From the point of view of the usefulness of the full costing for cost management in a company, it is important that this costing is a mandatory costing system, resulting from the provisions of the balance sheet law. The accounting system in force in Poland requires accounting subjects to determine the financial result and prepare the financial statements, including the profit and loss account, in accordance with the principles of full costing. This results from the provisions of the Accounting Act of 29 September 1994, according to which the cost of production of an asset on its own includes direct costs of manufacture of particular finished products, manufacture in progress and semi-finished products and a justified part of indirect manufacturing costs attributable to the period of their manufacture (Act, 1994).

Therefore, in the light of the considerations made so far, it should be concluded that the direct determinant of the total costs incurred by the unit is the volume of production and all costs incurred in a given period are the costs of the products manufactured. However, 
these assumptions are appropriate only if the capacity of the unit is fully utilized and if the share of indirect costs in total costs is relatively low. Unfortunately, in practice, these conditions are increasingly rarely met, due to, among others, a drop in the level of demand for manufactured products, which brings with it limited possibilities of using the available production capacity. Under these circumstances, the share of direct costs in total costs is systematically decreasing in favor of an increase in the share of indirect costs (Moskwa-Bęczkowska, 2019), which means that the full costing does not meet its conceptual assumptions. The division of costs into direct and indirect is therefore of little use in this situation. The allocation of indirect costs to the reference units, proportional to the adopted key, gives them a character of costs highly dependent on production volumes. It should be noted that indirect costs are mostly fixed costs, i.e. independent of production volumes. Another disadvantage of the full costing is the distortion of information on unit costs of products as a result of proportional allocation of indirect costs. The allocation keys used do not always correctly reflect the cause and effect relationships that exist between the costs allocated and the products manufactured. Moreover, this costing method is more useful in making long-term decisions than for the current needs of company management.

The weaknesses of the full costing system mentioned above resulted in the development and dissemination of other, so called modern costing systems, which include - among others activity-based costing, target costing or resource and process consumption accounting. The experience of the Author of the article from the implementation of the activity-based costing in public universities resulted in the fact that it is this concept of cost management that will be applied in the investigated manufacturing enterprise and the results of the conducted research will be presented in the second part of this article.

\section{Calculation of costs in traditional terms and according to the concept of activity-based costing}

In the efficient operation of companies, including in particular manufacturing units, the manner in which the level and structure of unit costs of finished products and manufacture in progress are determined is particularly important. This activity is referred to as cost calculation and plays a significant role in shaping the pricing policy. There are many different methods and variations of unit cost calculation in the literature and their selection is determined by the type of production. Due to the limited size of the article, only an additional calculation will be described in further considerations. This is the most frequently used method of unit cost calculation in multi-assortment manufacturing enterprises, with complex and multi-stage technological processes. It consists in separate calculation of production costs of each 
predefined calculation object ${ }^{1}$. In the additional calculation method, direct costs are allocated to the cost calculation object on the basis of source documentation (Nowak, Piechota, Wierzbiński, 2004). These costs are characterized by their relation to only one cost object to which they are entirely assigned. They do not involve any other cost object. Therefore, it is not necessary to allocate them in advance - by means of allocation ${ }^{2}$ keys - to various types of cost objects, which should be considered a definite advantage of such a method of direct cost allocation in defined cost objects. On the other hand, indirect costs, often also called common costs, as opposed to direct costs, are related to more than one cost object. This necessitates the use of appropriate accounting procedures. These costs are added to direct costs by means of appropriately selected allocation (distribution) keys. A big problem in the process of reliable calculation of unit costs with the analyzed method is the proper allocation of indirect costs to individual calculation objects. This is because the share of these costs in total costs increases as a result of, among others, continuous modernization of manufacturing technology and automation of manufacturing processes. In the traditional methods of calculation, indirect costs are grouped according to their origin and then settled for the basis of allocation, which is most often assumed to be direct costs (i.e. direct materials and direct labor). Generally, this method of allocating of indirect costs is considered to be 'superficial' because too little of it is attributed to the total cost of manufacture of products. This in turn significantly reduces the reliability of the calculated unit cost of the product. In addition, with a high level of indirect costs, their incorrect calculation provides irrelevant and misleading information, which contributes to making wrong decisions (Kłosowski, 2013). Often there are underestimations or overestimations of the costs of manufactured products, often these products are loss-making, even though the calculation carried out indicates their profitability (Świderska, 2003). There is also a need to obtain partial data from the course of individual phases of the manufacturing process, which is not possible in the additional calculation.

An alternative to traditional methods of unit cost calculation is their calculation according to the concept of activity-based costing (ABC). The basic assumption of this costing is that the activity of each business unit consists of a number of processes and activities necessary to manufacture and sell products or provide services (Skarżyńska, 2012). One of the most frequently cited interpretations of this issue is the definition developed by CAM-I (Consortium for Advanced Manufacturing - International). According to which activity-based costing is a methodology for measuring the cost and efficiency of activities, resources and cost objects. The costs of resources are allocated first for activities and then the costs of activities based on their use are allocated for cost objects. It therefore follows from this definition that the main elements of this costing are:

\footnotetext{
${ }^{1}$ Unambiguously defined products (goods, services) for which unit production costs are determined are considered to be objects of cost calculation.

${ }^{2}$ The allocation keys are certain auxiliary quantities of the nature of technical and economic parameters of the products which show an actual or contractual relationship with the costs to be allocated.
} 
- resources, i.e. the economic resources of the company concerned, such as materials, employees, buildings, machinery, equipment, etc.,

- activities, i.e. separate parts of economic processes, covering related activities necessary for the manufacture and sale of products, e.g. preparation of production, product quality control, packing and shipment of goods, invoicing, etc.,

- cost object, i.e. individual products or services for which unit costs are calculated.

In comparison with traditional cost calculation methods, a great advantage of the activitybased costing is the possibility to assign costs to products on the basis of the activities carried out, in order to produce it, and to determine the costs of those activities on the basis of information about the resources used in the production process. Figure 1 presents a schematic representation of the method of allocating costs both in the traditional approach and in the activity-based costing.
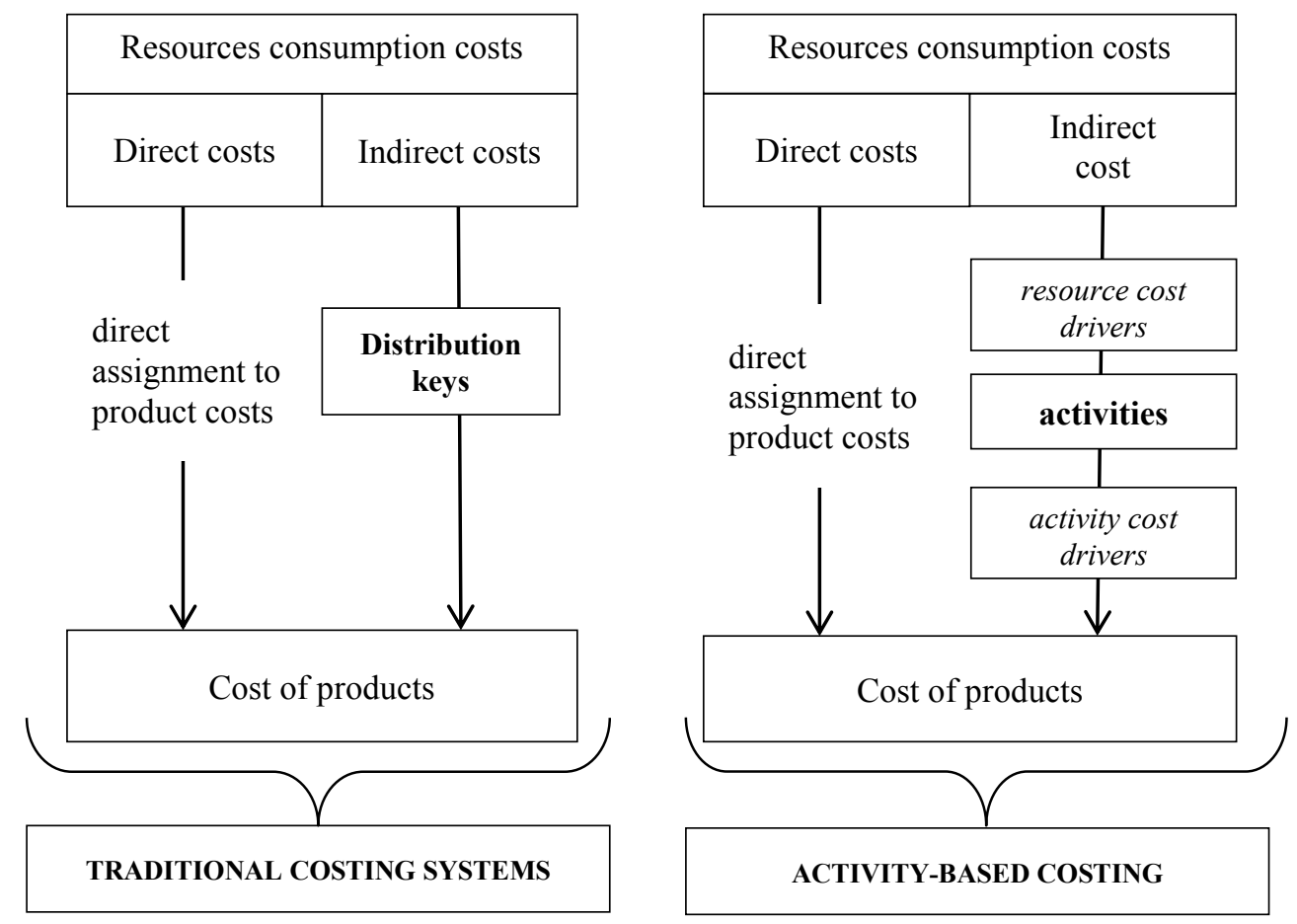

Figure 1. Traditional costing systems and activity-based costing. Source: Own elaboration.

As mentioned, the main disadvantage of traditional costing methods is the inaccurate manner of allocation of indirect costs for individual cost objects, i.e. a limited selection of distribution keys from which direct wages, man-hours or machine hours are most often chosen. In addition, indirect costs are traditionally grouped according to their origin. In the activitybased costing, however, there is a possibility to use a diversified number of allocation keys and indirect costs are grouped according to activities which are the cause of their incurring. The cost of manufacture of a given product is therefore the sum of the direct costs and the costs of all activities related to the manufacture of that product. In the analyzed method - as presented in Fig. 1 - indirect costs are allocated by means of many different bases (the so-called resource cost drivers and activity cost drivers) and in most cases they do not depend on the production 
volume, as is the case with traditional methods. This makes the activity-based costing a more accurate method of determining the cost of products manufacturing.

The application of this cost calculation requires a lot of preparation and its implementation is easiest to do according to the following steps:

1. the identification of relevant processes and activities taking place in a company,

2. the determination of the resource structure type of a company resources and the value of their consumption,

3. the definition of resource cost drivers,

4. the determination of the costs of the distinguished activities,

5. the definition of the activity cost drivers,

6. the allocation of indirect costs of individual activities to cost objects.

The stages defined in this way definitely facilitate the implementation of the activity-based costing in the company. It is worth noting at this point that the above procedure fully reflects the concept of activity-based costing in the theoretical perspective. The above mentioned stages will be used to analyze and present this costing in the case study, presented in the next article.

\section{Final thoughts}

The activity-based costing became a fixed element of the area of advanced management accounting tools. Although its implementation requires many organizational changes in the company, related to, among others, adjusting the principles of cost recording, identification of processes and activities, determination of first and second degree allocation keys or changes in the financial and accounting system, thanks to them the unit gains a precise cost management tool. The literature on the subject presents many research results concerning the dissemination of this costing method in entities of the market sector. However, despite its many advantages, there are still few entities that decide to implement it, which, as it turns out, is mainly due to the unfamiliarity with the assumptions and cost calculation procedures in this concept.

\section{References}

1. Accounting Act of 29 September 1994 (Journal of Laws No. 121, item 591, as amended).

2. Dobija, M. (1995). Rachunkowość zarzadcza. Warszawa: PWN.

3. Dobija, M. (1997). Rachunkowość zarzadcza i controlling. Warszawa: PWN.

4. Gabrusewicz, W., Kamela-Sowińska, A., Poetschke, H. (2002). Rachunkowość zarzadcza. Warszawa: PWE. 
5. Kłosowski, M. (2013). Koszty procesów w rachunku kosztów działań. Polskie Towarzystwo Zarządzania Produkcją.

6. Moskwa-Bęczkowska, D. (2019). Efektywne zarządzanie kosztami publicznych szkót wyższych w Polsce. Kielce: Kielce University of Technology.

7. Nowak, E. (1996). Teoria kosztów w zarządzaniu przedsiębiorstwem. Warszawa: PWN.

8. Nowak, E., Piechota, R., Wierzbiński, M. (2004). Rachunek kosztów w zarządzaniu przedsiębiorstwem. Warszawa: PWE.

9. Nowak, E., Wierzbiński, M. (2010). Rachunek kosztów. Modele i zastosowania. Warszawa: PWE.

10. Raiborn, C.A., Kinney, M. R. (2010). Cost Accounting. The United States: South Western Educational Publishing.

11. Skarżyńska, A. (2012). Rachunek kosztów działań - nowe spojrzenie. Zagadnienia Ekonomiki Rolnej, No. 3. Warszawa.

12. Sołtys, D. (2014). Rachunkowość zarzadcza przedsiębiorstw. Rachunek kosztów. Wrocław: Wrocław University of Economics.

13. Świderska, G. K. (ed.). (2003). Rachunkowość zarządcza i rachunek kosztów. Warszawa: Difin. 